\title{
我が国における条坊制都市の成立をめぐって
}

一研究の現状と展望——

木原克司

\begin{tabular}{|c|c|}
\hline はじめに & III 難波宮・京 \\
\hline I 藤原京と倭京 (飛鳥京) & $\mathbb{N}$ 前期難波宮の造営時期をめぐる諸問題 \\
\hline (1) 藤 原 京 & $\mathrm{V}$ 摂津 - 河内の直線古道と前期難波京 \\
\hline （2） 倭京（飛鳥京） & おわりに \\
\hline II 大津宮・京 & \\
\hline
\end{tabular}

はじめに

我が国に和沙る古代の宮室・都城の研究は, 1954年に始末る平城宮・難波宮の発掘調査を契 機として，大津・藤原・恭仁・長岡・平安の諸 宮都で継続的に調査が実施され，ここ30年近く の間に大きく前進した。それは偏に各宮室・都 城の構造の比較研究が可能となったことに負う ところが大きいように思われる。そして，それ らの成果をもとに，近年中国や朝鮮の都城との 比較研究も精力的に和こなわれるようになって 来た。

その結果，平城京や平安京に代表される北に 宮室を配し，その南に碁盤割状の街区を設けた 日本の都城は，単なる隋・唐の長安城の模倣で はなく，漢・魏・晋以来の北魏洛陽城にみられ る『周礼』型の中国の正統的な都城の理想型を よく理解し，それに基ついて設計・造営された と言われている。

岸俊男の指摘にあるように, 平城京の原型は 藤原京に求められ, 近年の発掘調査により藤原 京が条坊による街区を伴ら京であったことも間 違いのないところとなって来た。果して, 藤原
京が我が国条坊制都市の初現であるのか，ある Wは，藤原京以前の難波宮，大津宮や飛鳥の諸 宮に条坊制による街区が伴わなかったのであろ らか。これは，今日我が国に和ける都城制研究 上の大きな課題となっている。また，最近では 飛鳥や藤原宮・京周辺での新たな考古学上の知 見が契機となって，学界では半ば定説化してい た岸俊男による藤原京城 [注2)119-120頁〕も再検 討を迫られているのが現状である。

本稿の目的は, 藤原京をはじめとして藤原京 以前の倭京, 大津宮和よび難波宮の調査・研究 の現状を整理しつつ，藤原京にみられるような 中国の正統的王城の構造形式にのっとった条坊 制都市の成立時期を検討するところにある。な お，筆者が問題とする条坊制都市とは，内裏・ 朝堂院から成る宮室を中心とする一定の広がり を有する宮域の周囲和よび南方に，側溝を伴う 幅の広い道路により基盤割状に区画された街区 の付属する都市を意味する。

\section{I 藤原京と倭京（飛鳥京）}

（1）藤原京 藤原京は，持統 8 年 (694) 12 月 6 日に宮室が飛鳥浄御原宮から藤原宮に遷され

1）岸俊男「日本の宮都と中国の都城」（上田正昭編『都城』，社会思想社，1976）99-139頁。 岸俊男『日本の古代宮都』，日本放送出版協会，1981，125-130頁。

2）岸俊男「宮城叔よび京域の推定」（奈良県教育委員会編『藤原宮』，1969）106一126頁。 
て以来，和銅 3 年 $(710)$ の平城遷都まで 15 年間 古代国家の拠点として栄えた。

京域についてはじめて具体的な復原案を提示 したのは喜田貞吉であるが，昭和14年〜18年に かけて橿原市高殿町に遺存する大宮土壇付近で の日本古文化研究所による発掘調査が実施され， 大宮土壇を大極殿とする藤原宮朝堂院の構造が 明らかにされた。

藤原京の京域が確定される契機となったのは， 昭和41年末に始まる国道 165 号線バイパスに伴 う緊急発掘調査である。この調査で宮域を画す る大垣が, 宮の北・東・西の 3 面で検出され宮

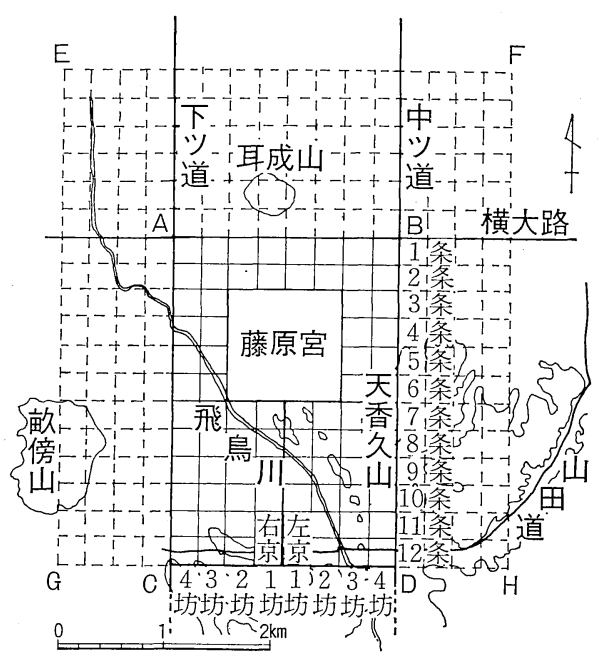

第1図 岸説藤原京 $(A \cdot B \cdot C \cdot D)$ 之秋山説 大藤原京 $(\mathrm{E} \cdot \mathrm{F} \cdot \mathrm{G} \cdot \mathrm{H})$
域が定まった。

岸俊男はその成果をもとに地形図上での検討 を加光，第 1 図に示すように横大路を北京極, 中ツ道を東京極, 下ツ道を西京極, 山田道を南 京極とする京域を想定し，その範囲内に左京・ 右京とれぞれ12条 4 坊の条坊地割が施行された としだ注2)106一126頁】。

昭和44年以降, 奈良国立文化財研究所により 京域内での発掘調査が進められ, 各所で岸の想 定条坊地割に合致する条坊道路遺構が検出され ている。しかし，京域を限る京極大路について は，未だ十分に調查が及んでおらず，とりわけ 岸が東京極にあてた中ツ道については，大官大 寺の調查や京域南方の石神遺跡の調査で道路の 存在について否定的な見解が提示されている。 すなわち，前者では東京極大路中軸線（中ツ道 中軸線）上で南北方向の流路が検出され，少な くとも大官大寺がこの地で営まれていた時期 （8世紀初頭前後）まで流路として存続していた ことが明らかにされた。また，後者では中ツ道 の想定位置に道路遺構は検出されず，7 世紀後 半にはとの位置を横断する東西塀が造られたこ とが確認されている。

さらに, 最近の調査では, 京域外の地域で京 の条坊に一致する道路遺構が 2 力所で発見され， これらをもとに秋山日出雄・ 千田稔により新た な京域復原案が提示された。

3）喜田貞吉『帝都』，日本学術普及会， 1915，129-141頁。

4）日本古文化研究所『藤原宮阯伝説地高殿の調查一』，1936，15一76頁。

同『藤原宮阯伝説地高殿の調查二』，1941，1-43頁。

5) · 岸が 12 条・4 坊の条坊地割を設定したのは, 戸令に 4 坊に 1 人の坊令を置くとみえることや, 職員令左右京職条に 12

人の坊令を置くとあることを根拠としている。

6）奈良国立文化財研究所「大官大寺第 8 次の調査」，飛鳥・藤原宮跡発掘調查概報13，1983，62一72頁。

同「大官大寺第 9 次の調査」, 飛鳥・藤原宮跡発掘調査概報14, 1984, 56一64頁。

7）奈良国立文化財研究所「飛鳥浄御原宮推定地の調査一石神遺跡」, 飛鳥・藤原宮発掘調查概報12，1982，55一61頁。

同「飛鳥浄御原宮推定地の調査一石神遗跡第 2 次調查」, 飛鳥・藤原宮発掘調查概報 $13,1983,11$ - 19 頁。

同「石神遺跡第 3 次調査」, 飛鳥・藤原宮発掘調査概報14，1984，39-52頁。

同「石神遺跡第 4 次調査」, 飛鳥・藤原宮発掘調査概報15，1985，55一68頁。

同「石神遺跡第 5 次調査」，飛鳥・藤原宮発掘調査概報16，1986，45一53頁。

8）中井一夫・松田真一「橿原市葛本町藤原京条坊関連遺構の調査」, 奈良県遺跡調査概報1979年度, 1981, 192一199頁。 橿原考古学研究所編『橿原市院上遺跡』, 1983, 11-17頁, 154-159頁。

9）秋山日出雄「藤原京の京域考一内域と外京の想定一」, 橿原考古学研究所紀要考古学論改第 4 冊, 1980, 1-8 頁。 同「藤原京と飛鳥京の京域考」, 地理第25巻第 9 号, 1980, 29-37頁。

同「八省院＝朝堂院の祖型」((財)大阪市文化財協会編『難波宮址の研究第 7 (諭考編)』，1981）220-224頁。 
秋山の想定する藤原京域は，第 1 図に示すよ うに岸の想定した東西 4 里, 南北 6 里の京域を 「内城」とし，その外側に東西 2 里 (4坊) づつ, 北に 3 里 (6 条) の「外京域」を伴うものであ る。な抏, 秋山のこの想定は, 横大路北方 3 里 以南で古墳が残存しないことや横大路以北で中 ツ道・下ツ道のそれぞれ東・西 2 里外方の線が， 大和国十市郡の東・西の境界線であったことな どを主たる根拠とするものであり，一般には大 藤原京説と称されている。

これに対して，千田は大和飛鳥地域に令制50 歩（約 $88 \mathrm{~m}$ ) の方格プランが存在したことを想 定し，その北限が岸の復原による藤原京 10 条大 路の位置にあたるとした。そして，そのライン から北に50歩の 1.5 倍である75歩の方格地割が 施行され，それが『日本書紀』天武 5 年 (676) 是年の「将レ都=新城_。而限内田園者, 不レ問= 公私二, 皆不耕悉荒。然遂不都矣。」から椝わ れる計画地割であり, 藤原京は新城の地に新に 設定されたものであるとする新見解を示し，岸 説の 10 条大路を南京極とし, 北側に 12 条のライ ンを北京極とする京域を想定した。

これら両説に対しては，藤原京・平城京を中 心に都城制地割について精徽な研究を展開し, さらに飛鳥京域にも考古資料をもとに検討を加 党た井上和人による批判がある。

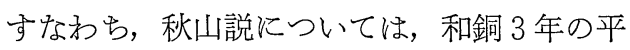
城遷都後, 藤原京域の中で「内城」ょりも「外 京域」が先に条里的に開発されたという見解が， 先の橿原市葛本町で検出された条坊一致道路の
存続年代（奈良〜平安初期）と合致しなく，京域 内の条坊道路側溝や宮域内外の濠, 溝などが平 城遷都後, 埋没しあるいは人為的に埋め戻され たといら従来の調查成果とも矛盾すると指摘し ている。

千田説に対しては，これまでの発掘調査で岸 説の 10 条大路以南に拈いて条坊道路の存在が確 認されていない事実を根拠に一応の評価はでき るものの, 南京極決定に際する誤測や条里制と の混同が認められるとした。

しかし, 岸の想定京域 (8坊12条) には元来 南京極が山田道より約 $90 \mathrm{~m}$ 南に位置するという 問題が内包されて和り，10条大路以南で未だ条 坊道路が検出されないといら考古学上の事実を 重視するなら，千田の復原京域もより具体性を 帯びてくるように思える。

このよらに，藤原京域にはまだ不確定な要素 が多く，今後の考古学的な検証を俟たねばなら ないものの，藤原京が中国都城の影響を強く受 けた条坊制による都市であったということは， 考古学的にもすでに害証されており，まず間違 いのないところと考觉らる。

(2)倭京 (飛鳥京) 藤原京以前の飛鳥地域に 「京」と称される一定の広がりを持った行政区 域が成立していたことは『日本書紀』の記事か ら窥える。

すなわら，「倭京」「倭都」といら呼称は，孝 德天皇白雉 4 年 (653) 是歳条の「太子奏請日, 欲三冀遷=于倭京一」をはじめとして天武元年 （672）9 月条の「詣=于倭京，而御=嶋宫_」に

$\nearrow$ 同「日本古代都城制の源流」(舟ケ崎正孝先生退官記念会編『舟ヶ崎正孝先生退官記念畿内地域史論集』，1981）147 -171頁。

10）千田稔「歴史地理学に和ける「復原」から「意味論」へ一藤原京を事例として一」(京都大学文学部地理学教室編 『地理の思想』１982）121-133頁。

同「倭京・藤原京問題と地名」, 地理 7 月号臨時增刊号，1982，128-131頁。

11）井上和人「藤原京一新益京造営汇関する諸問題一」, 仏教芸術154号, 1984, 37-46頁。

12) 秋山日出雄「大和国条里復原図解説」(奈良県立橿原考古学研究所編『大和国条里復原図』, 奈良県教育委員会, 1980) 37 -38頁。

13）奈良国立文化財研究所「小稂田宮推定地の調查」，飛鳥藤原宮発掘調查報告 I，1976，5-44面。 同「和田廃寺の調查」, 飛鳥・藤原宮発掘調查概報 $5,1975,39-43$ 頁。

同「和田廃寺第 2 次の調査」, 飛鳥・藤原宮発掘調査概報 6，1976，38-46頁。 
至る間にしばしば使用されている。そして，や や時を置いて天武 5 年 (676) 9 月条の「王卿 遣=京及畿内_, 校=人別兵-」から持統 9 年(695) 6 月条の「遣二大夫謁者-, 詣=京師及四畿内諸 社=請雨」に至っては「京」「京師」といら語が しばしば現れる。

最近の都城研究の現況から察すれば，その適 否は別として前者を南北に狭隘な飛鳥盈地内を 宮室が転々とした時期の行政区域としての倭京， 後者を天武期に新しく成立した倭京と解すべき ようである。ところで，飛鳥京という呼称は歴 史的に存在しない用語であるが，その使用例か ら推察すると，前者の倭京の意で用いられてい るよらである。

飛鳥地域で 7 世紀代に造営されたと考光られ る宮室・寺院などが一定の方格地割に基づいて 配されていることを指摘し，その方格地割が飛 鳥京 (倭京) の実態と深くかかわってくるので はないかとする見解が，網干善教，岸俊男，秋 山日出雄, 藤岡謙二郎, 千田稔の諸氏から提示 されて来た。これら諸説が生じた大きな理由は， 方格地割設定に際する基準線や方格の基本単位 が異なるところにある。各説それぞれ問題があ るが，一応以下に各説の概要を簡単に述べてお <。

網干は，橘寺の塔心礎と大官大寺の塔跡とが 一直線上に並ぶことや，橘寺塔と飛鳥寺塔との 心心間距離が 600 小尺である点をもとに，飛鳥 地域に令小尺 600 尺方眼の方格地割の存在を想 定した。

それに対して，岸は山田道以南の地域に山田 道と中ツ道を基準線とする 1 町（約 $106 \mathrm{~m}$ ) 四方
の方格地割が想定できるとし, 飛鳥寺・川原 寺・橘寺の伽藍中軸線, 伝飛鳥板蓋宮の遺構, さらには酒船石・亀石の配置がすべてとの地割 線に規制されていることを指摘した。

また，秋山は中ツ道を南北の基準線とし，豊 浦寺塔址を東西のそれとして網干と同様，令大 尺500 尺四方すなわち 100 歩の方格地割が施行 されたとの見解を提示し，飛鳥京の条坊域を大 官大寺の南を北京極, 川原寺の南の古道を南京 極とし，東西の限界を亀石と治田神社境内所在 の立石として10条 8 坊の条坊を復原した。しか し，一方では横大路・上ツ道・下ツ道と橘寺北 門前を東西に走る古道とに囲まれた東西 8 里・ 南北 9 里の平城京や平安京と同規模の京域を想 定して括り，理解し難い一面がある。

藤岡は藤原京の東南隅に接し, 山田道を北京 極とし中ツ道の南への延長線を朱雀大路として， 令大尺 750 尺（令小尺 900 尺）の $1 / 2$ 坊の大 きさとした 8 坊 12 条の京域(藤原京の $1 / 4$ )を想定 した。

さらに, 千田は飛鳥寺中軸線と飛鳥京跡宮殿 遺構群（伝承飛鳥板蓋宮上層遺構）の中軸線とを 結ぶ線を南北の基準線とし，山田道を東西のと れとして令制 50 歩 $(250$ 高麗尺 $\times 0.353 \mathrm{~m}=88 \mathrm{~m})$ の方格を設定すると，飛鳥の寺院，遺跡や石造 物がそれによく符合するとした。

しかし，これら諸説に対して井上和人による 詳細な検証が持こなわれ，いずれの説も事実関 係に怙ける誤認や暖昧さが認められ成立し難い とされている。そして，井上は「何よりも遺跡 ・遺構の示す事実による限りどのような方格地 割の存在も実証できない。和そらく6・7 世紀

14）網干善教「倭京 (飛鳥) 地割の復原一飛鳥地方の寺院跡を中心として一」, 関西大学考古学研究紀要 $3,1977,36$ 一 50 頁。

15）岸俊男「飛鳥と方格地割」，史林53巻 4 号，1970，1-41頁。

16）秋山日出雄 「「飛鳥京」と大津京都制の比較研究」（橿原考古学研究所編『飛鳥京跡一』，奈良県教育委員会，1971） 269-358頁。

17）秋山日出雄「飛鳥京」(藤岡謙二郎編『講座考古地理学 2 』, 学生社, 1983) 33-46頁。

18）藤岡謙二郎「(2)都市」(藤岡謙二郎編『日本歴史地理総説古代編』，吉川弘文館，1975）22一23頁。

19）千田稔「道と地割の計画一河内磯長谷の古墳配置の問題に関連して一」, 環境文化第51号，1981，38一-52頁。

20）井上和人「飛鳥京域論の検証」，考古学雑誌第 71 巻第 2 号，1986，43-78頁。 
代の飛鳥地域には，少なくとも都城の条坊制の 前提となるような方格地割はなかったと考光 る」と結論している[注20)75頁〕。

井上のこの見解をも含めて飛鳥の方格地割に ついては，今後の発掘調査の成果をもとにさら に検討を加える必要があろらかと思われる。し かし，これまでの飛鳥地域に郝ける発掘調查の 成果や藤原宮出現末での 7 世紀代の宮室が狭险 な飛鳥地域内を転々とする事実を考慮すれば， 藤原京に見られるような条坊地割を伴う条坊制 都市の成立はをず考兄られない。屯しろ，狩野 久や今泉隆雄の指摘にあるような自然的に形成 された農村的な京の存在が想定される。

それは，これまでの発掘調査で先の方格地割 説の基準線ともされている中ツ道を含めて，藤 原宮・京内で見られるような直交する道路遺構 の検出例がなく，飛鳥寺近辺では，むしろ方格 地割の存在にとって不定的な石敷の斜向道路が 検出されていることからも裏付けられよう。

ところで，最近藤原宮域内の全域で藤原宮の 造営に先立って造られたいわゆる先行条坊道路 と称する道路遺構（第 2 図）が，さらに，岸俊 男の想定藤原京域外で藤原京条坊地割々関連す る道路遺構がそれぞれ検出されて和り，これら の遺構を天武朝の倭京と結びつけて理解しよう とする見解が岸俊男・ 千田稔・ 木下正史から出

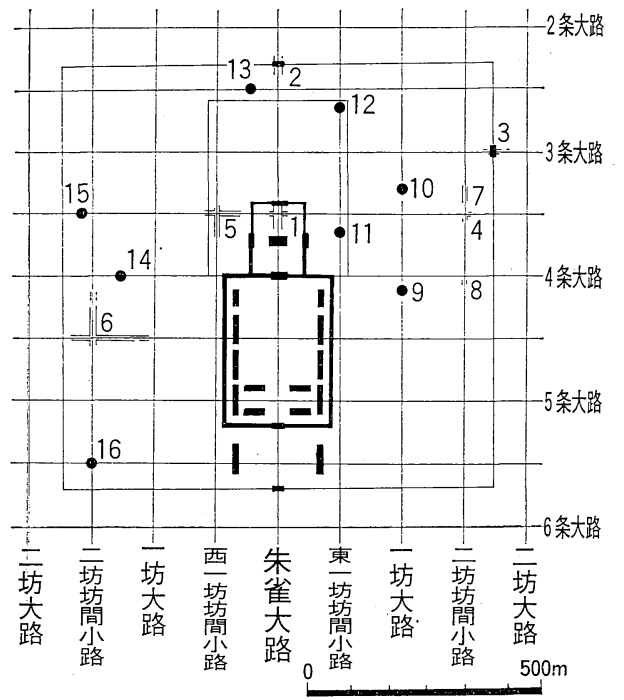

第 2 図藤原宮域内先行条坊道路検出地点

されている。3 氏とも『日本書紀』天武 5 年 (676) 是年条の「将レ都=新城-。而限内田園者, 不レ問二公私，皆不レ耕悉荒。然遂不々都矣」に 見觉る新城を新しい都城，すなわち倭京をさす と解して和り，千田により岸説藤原京の 10 条大 路以北に令制 50 歩の 1.5 倍である75歩を単位と した具体的な倭京プランが復原されている。 ところで，この宮内先行条坊道路やそれに規 制された掘立柱建物群の性格をめぐって，先の 天武朝倭京説以外飞諸説があり確定し難い一面 がある。つまり，藤原宮・京の造営と関連する

21）狩野久「律令国家之都市」（原秀三郎他編『大系日本国家史 1 古代』，東京大学出版会，1975）233一234頁。

22) 今泉隆雄「律令制都城の成立と展開」(歴史学研究会・日本史研究会編『講座日本歴史 2 古代 2 』, 東京大学出版会, 1984）43一67頁。

23）奈良国立文化財研究所「飛鳥寺南方石敷広場の調査」，飛鳥・藤原宮調查概報13，1983，28-31頁。 橿原考古学研究所「飛鳥京跡第77次調査」，奈良県遺跡調査概報1980年度，1981；267-272頁。

24）奈良国立文化財研究所「藤原宮第18次の調査」，飛鳥・藤原宮発掘調査概報 6，1976，16一24頁。 宮沢智士・菅原正明「2 遺構」(奈良国立文化財研究所編『飛鳥・藤原宮発掘調查報告 II 』, 1977）15一16頁。 奈良国立文化財研究所「藤原宮第20次（大極殿北方）の調查」，飛鳥・藤原宮発掘調査概報 8，1978，3-13頁。 同「藤原宮第21-1 次の調査」, 飛鳥・藤原宮発掘調査概報 8，1978，23-24頁。

同「藤原宮第27次の調査」, 飛鳥・藤原宮発掘調查概報10，1980，10一-17頁。

同「藤原宮東方官语地域の調査 I (第30次)」，飛鳥・藤原宮発掘調査概報11，1981，12一15頁。 同「藤原宮東方官地域の調査 (第23-4 次)」, 飛鳥・藤原宮発掘調査概報12，1982，24-28頁。 同「藤原宮東方官衙地域の調査（第38・41・44次）」, 飛鳥・藤原宮発掘調查概報15，1985，4-24頁。

25）岸俊男「都城々律令国家」(『岩波講座日本歴史 2 』，岩波書店，1975）259-264頁。 同『日本の古代宮都』，日本放送出版協会，1981，47一-48頁。

26）千田稔「歴史地理学に括ける「復原」から「意味論」へ一藤原京を事例として一」(京都大学文学部地理学教室編 『地理の思想』，1982）121-126頁。

27）木下正史「藤原宮域の 開発一宮前身遺構の性格について一」（奈良国立文化財研究所編『文化財論叢』，同朋社， 1983）379-380頁。 
遺構とみる解釈, 京造営に伴って先行する民家 が建物の配置を条坊に合わせて造り替えたもの か，あるいは，京造営に伴ら役民衆の集住を示 すもののいずれかとする解釈, さらには，宮の 建設が予定された造成地の維持管理をはかるた めの排水処理体系であるとする考光方(注11)4043頁了などがある。

しかし，仮に岸・千田・木下の言らように， 天武朝の倭京が飛鳥だけに留まらず後の藤原京 城を含めた広い範囲に抏よんでいたとしても， 当該期の宮室は南方の飛鳥地域にあった飛鳥浄 御原宮であり，乙かも飛鳥地域で藤原京に見ら れるような条坊道路が検出された例がないとい ら実情を考学ると，天武朝倭京での条坊制都市 の成立もまず想定し難いと言えよう。

\section{II 大津宮・京}

天智天皇 6 年 (667) 3 月の近江遷都から同 10 年12月の天皇崩御に至るわずか 5 年足らずの宮 都であった大津宮・京をめぐる研究は，18世紀 の儒学者であった近江膳所藩の寒川辰清に始ま る。

大津京について初めて学問的な考究を行い, 具体的な京域を想定したのは喜田貞吉である。 喜田は大津京は大化の難波京の制を踏襲したも のであるとし，大津北郊の条里遺構をるとに東 西10町，南北20町の京域を設定した。

条里制に基づく京域の研究は，その後米倉二 郎, 藤岡謙二郎, 秋山日出雄 [注16)310一-328頁] に より継承され，それぞれ想定条坊案が提示され
た。米倉は湖西の滋賀里から南滋賀，錦織付近 の正南北地割をもとに条里復原を行い，1 条の 起点となる錦織の小字御所之内を宮室跡とみな 乙, 条里の 1 里 $=1$ 坊と考光て大津京域を想定 した。

一方藤岡は，米倉の条里復原を再検討すると ともに，滋賀里から南滋賀，錦織付近の南北の 方格地割中に条里の 360 尺よりやや大きい 450 尺前後の間隔を示す地割の存在を認めた。そし て，それをもとに北辺を滋賀里の小字「蟻之 内」の北とし，西限を条里の里境でもある壹笠 山を通る南北線とし， 1 坊 450 尺とする 8 坊 12 条の京域を復原した。

また, 秋山は滋賀郡坂本以南, 大津近辺まで に遺存する南北地割を斜向地割後に施行された 大津京造営に関連する特殊地割と推定し, 北京 極を滋賀里の字塚ノ下の北限線，南京極を錦織 ・山上の境界線とし，飛鳥京と同じ令制 100 歩 を 1 条(坊)とする10条 6 坊の京域を想定した。

大津宮・京の発掘調査は, 昭和 46 年に始をる 国鉄湖西線敷設に伴う発掘調査以来継続的に実 施されて来た。とりわけ，昭和 49 年末から昭和 50 年にかけて錦織 2 丁目字御所之内で行われた 発掘調査では，大津宮関係の門 (S B 001) と回 廊 (S C 001) が初めて検出され，その後の錦織 近辺の発掘調査の成果と合わせて錦織地域に大 津宮が営まれたとする説が有力となって来てい る。

林博通は錦織周辺での検出遺構をもとに第 3 図に示す大津宮復原図を作成しているが，宮の

28）宮沢智士・西弘海「考察 1 遺跡」（奈良国立文化財研究所編『飛鳥・藤原宮発掘調查報告 II』，奈良国立文化財研 究 所, 1978) 80-83頁。

29）鬼頭清明「藤原京条坊遗構について一近年の発掘調查結果から一」、『仏教芸術』第122号，1979，35頁。

30）享保19年（1734），藩令により 5 年を費やして近江国の地誌『近江興地誌略』を著した。

31）喜田貞吉「大津京遷都考」’’歴史地理15の $1 \cdot 2,1910,5$-10頁, 133-142頁。

32）米倉二郎「条里よりみたる大津京」, 歴史と地理 34 の $1 ， 1934 ， 1$-17頁。

33）藤岡謙二郎「古代の大津京域とその周辺の地割汇関する若干の歴史地理学的考察」, 人文地理 23 巻 6 号, 1971,1 15頁。

34）宮城（域）については，北限を条坊北辺と同じ字「儀の内」の北辺に，南限を現在注汸東流する際川に想定してい る。

35）乙かし，秋山の想定京域では宮域の位置が明らがされていない。

36）湖西線関係遺跡発掘調查団『湖西線関係遗跡調査報告書』，真陽社，1973。 


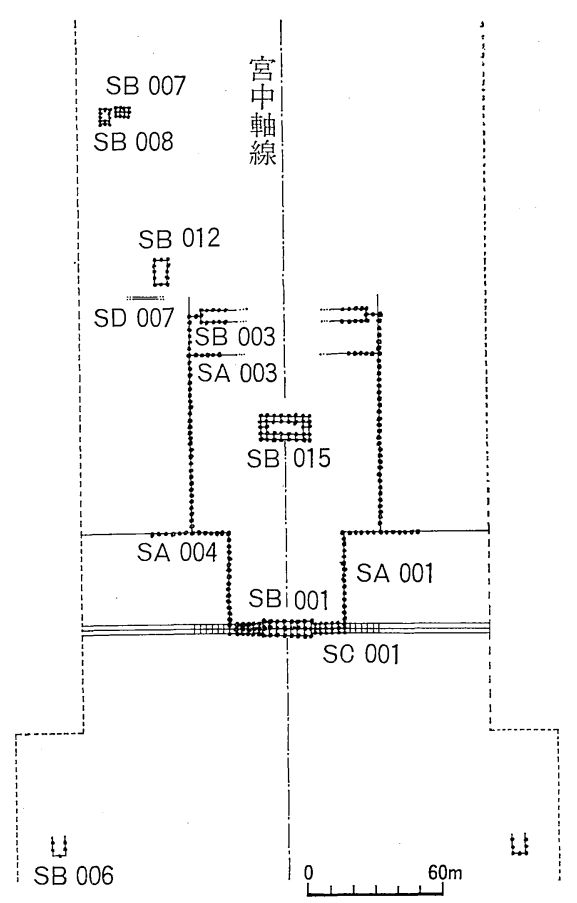

第 3 図大津宮復原図

（林博通『大津京』より）

全体像については，地勢からみて宮の規模は比 較的小規模で，官衙や官人の宅地なぞは南滋賀 や滋賀里，穴太などの扇状地に分散的に配置さ れたものと考朰てい。

しかし，これら錦織地区での検出遺構につい ては，各遺構の方位が一定しないこと，遺構の 年代が不明確であることなどを理由に大津宮以 外の官衙とする見解もあり，確実に大津宮の遺 構であると断定するのにはまだ問題があるよう である。

もし，林の指摘するように錦織地区に大津宮 が所在したとしても，正殿と考学られている掘 立柱建物（S B 015）や門（S B 001）の規模が前
期難波宮や藤原宮に比してきわめて小さい点や 北を柳川，南を不動川により画されるといら地 形的な狭险さを考慮すれば，岸俊男の指摘にも あるようにかなり規模を縮小した，しかも変則 的な配置の宮室を想定しなければならない。

また，先の藤岡・秋山の条坊プランや最近千 田稔の提示した令制方50歩の条坊プラン゙にして も，これまでの大津北郊の発掘調查でそれらの 存在を裏付ける遺構はまったく検出されて和ら ず，発掘調査に関係する林博通自身も条坊地割 の存在には否定的である。

このように，これまでの発掘調査の成果から 窺うかぎり，大津宮には藤原京にみられるよう な条坊制都市の存在はまず考光られない。もし 地割が存在したとしてる，それは統一的な地割 ではなく，宮周辺部や穴太・南滋賀などの寺院 を中心とした局部的な地割であったと考えられ る。

\section{III 難波宮・京}

難波宮については，昭和 29 年以来今日に到る 約32年にわたる発掘調査により，ほぼ中軸線を 同じくする前・後 2 時期の内裏・朝堂院を南北 に配する宮殿遺構が検出されている。

前期難波宮は，中心部建物の全面に火炎痕跡 が認められることから朱鳥元年 (686) 正月に焼 失した天武朝難波宮であることは間違いないが， その創建は白雉 3 年 (652) 飞完成した孝徳朝の 長柄豊碕宮飞遡及するとされ，後期難波宮は， 神亀 3 年 (726) 10月から造営に着手された聖武 朝の難波宮に比定されている。

37）林博通『大津京』, ニュー・サイエンス社，1984，86一-87頁。

38）丸山竜平「近江大津宮錦織遗跡の諸問題覚書一皇子山を守る民衆の視座から一」（日本史論叢会『歴史に和ける政治 と民衆』，日本史論叢会，1986）93-125頁。

39） S B 015 (桁行総長 $21.9 \mathrm{~m}$ ，梁間総長 $11.1 \mathrm{~m}$ ）に対し，前期難波宮の内裏前殿は $36.30 \times 18.75 \mathrm{~m}$ であり，藤原宮大 極殿は $35.54 \times 18.18 \mathrm{~m}$ である。さらにS B 001 (桁行総長 $21.4 \mathrm{~m}$ ，梁間総長 $6.4 \mathrm{~m}$ ）に対し，前期難波宮内裏南門は

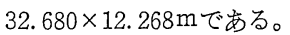

40）千田稔「畿内特よびその周辺に和ける古代の水運と港津」，環境文化第55号，1982，45一68頁。

41）沢村仁「奈良時代以前の古京」（三上次男・楢崎彰一編『日本の考古学叫』，河出書房，1967）34-35頁。 中尾芳治「難波宮址第16・17・18 $21 \cdot 31$ 次遺跡調査報告」(『難波宮址の研究第 6 』, 難波宮址顕彰会・大阪市立大 学難波宮址研究会，1970）99-104頁。 
この前・後両期の難波宮に条坊制に基づく京 が存在したか否かについては，喜田貞吉が『帝 都』で大化の改新詔の京師条に基づいて，中国 の長安城を模した条坊を備えた京城が長柄豊碕 宮に执いて初めて成立したと述べて以来永く論
議されて来た。しかし，具体的な条坊復原案が 提示されたのは，前・後両期の難波宮の内裏・ 朝堂院等の宮中枢部の構造がほぼ明らかとなっ た1970年以降であり，沢村先，藤岡謙二郎，長 山雅一，木原克司により第4 図のような京域が

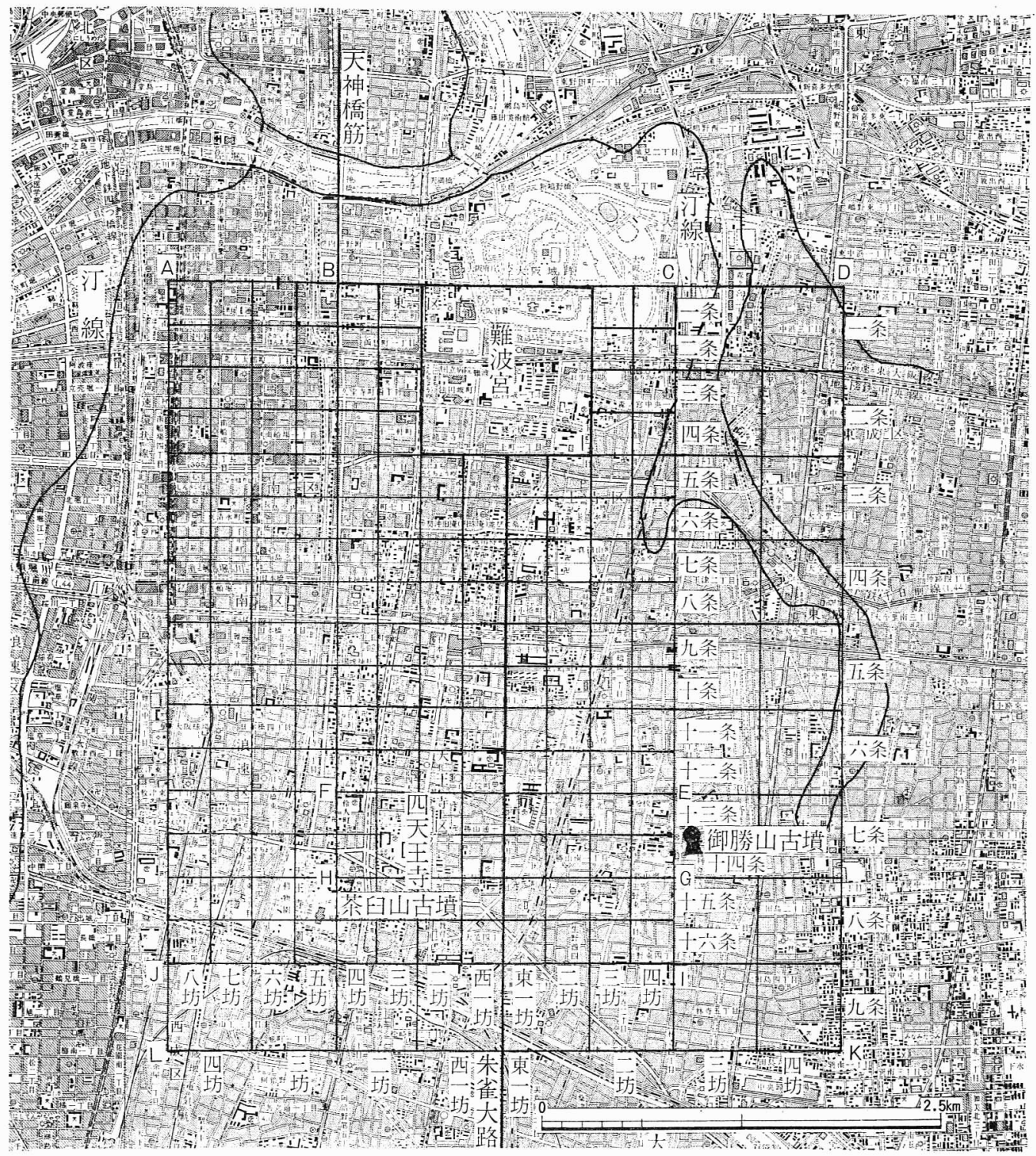

第 4 図 難波京復原案

$\begin{array}{lllll}\text { 前期難波京沢村説 } & \text { ACIJ } & \text { 後期難波京 } & \text { 藤岡説 } & \text { A D K L } \\ & \text { 藤岡説 } & \text { B C E F } & \text { 沢村説 } & \text { ACI J } \\ \text { 長山説 } & \text { B C G H } & \text { 木原説 } & \text { B C G H }\end{array}$

42）沢村仁「難波京について」(難波宮址影彰会・大阪市立大学難波宮址研究会『難波宮址の研究第 6 』, 1970, 1-12 面。

同「都城の変遷一古代の都市計画とその内容」(『古代史発掘9—埋れた宮殿と寺』，譜談社，1974）90-92頁。 
復原されている。

これらの推定京域は, 宮中軸線延長上に遺存 する古道痕跡，四天王寺周辺に残る令小尺 900 尺四方の地割，古地名などをもとに復原された ものである。中でも沢村説は船場・島の内周辺 に残る町割りをも条坊の痕跡とみなす点に, 長 山・木原説は前・後期に見解が分かれるものの， 茶臼山・御勝山両古墳を京域内に含めない点に それぞれ特徵がある。

しかし，筆者が京域復原の際の根拠とした奈 良時代初頭の推定汀線や『続日本紀』天平勝宝 5 年 (753) 9 月の「摂津国御津村南風大吹, 潮 水暴溢壤三損盧舎一百十餘区一漂三没百姓五百 六十餘人一。並加=賑恤一。仍追三海濱居民_遷三置 於京中架地-。」に見られる御津村の位置を考慮 すれば，沢村の令小尺 900 尺を 1 坊とする南北 16 条, 東西 12 坊の前期難波京や藤岡の令小尺 1, 800 尺を 1 坊とする南北 9 条, 東西 8 坊の後 期難波京のような広大な京域は想定し難いと言 光よう。

また，岸俊男は具体的な京域を図上に示さな かったが，難波長柄豊碕宮に難波京と呼ぶべき 条坊制都城が付属していたことを証する確かな 文献史料の初見を『日本書紀』天武 8 年11月条 の「初置=関於龍田山・大坂山。仍難波築=羅 城。」とし，少なくともこの時点で難波京が存 在していたと想定できると結論した。そして， 四天王寺東方に明瞭に遺存する令小尺 900 尺 (約 $265 \mathrm{~m}$ ) の方格地割をもとに，難波宮を北中 央飞置き，東を猫間川，西を東横堀川で限った 上町台地上に東西 8 坊, 南北 12 条 $+\alpha$ の藤原京
にくらべてやや縦長の都城を想定した。

さらに，難波京の完成時期を後期難波京に求 める吉田晶は，木原説の北と南に岸俊男の指摘 に従って 1 ～2坊を付加した京域を想定するの が妥当であるとしている。

これらの想定京域は，いずれも仮説の域を出 ず，未だ考古学的な実証を得ていないのが現状 である。ただ，後期難波京については，確実な 条坊地割の存在を示す遺構は未だ検出されてい ないものの，近年の発掘調査で，条坊地割に関 連すると思われる奈良時代の工字状の溝（上本 町 4 丁目)を始めとして，推定難波市に近い上本 町 $9 丁$ 丁目での奈良時代の棈円形井户，西京極に 近い両替町での奈良時代の方形井戸の検出, さ らには，推定朱雀大路沿いの筆ヶ崎町，北山町 での奈良時代の遺構・遺物の出土など，筆者の 想定京域のほ葟全域にわたって後期難波京時代 の遺構・遺物が検出されて和り，京の存在はほ 核間違いのないところとなって来ている。

ところで，前期難波京の成立時期について， 文献史学の分野から先の想定京域とからませて 種々の見解が提示されている。

狩野久は，豊碕宮段階にはとれまでの宮とは 異なって中国式宮城プランの導入による一定度 の前進を示す宮が造営され，宮の南門から南に 直進する官大道を基準として飛鳥の方格地割の ような条里制地割が施行されたのであり，沢村 ・藤岡両氏が復原したような難波京は，天武朝 あるいは聖武朝に求めるのが至当であるらとし ている(注21)235一-236頁〕また，吉田晶は孝徳朝 の段階では宮の中軸線を南に延長する「難波大

\43） 藤岡謙二郎「古代の難波京域を中心とした若干の歴史地理学的考察」（織田武雄先生退官記念事業会編『人文地理学 諭叢』，柳原畫店，1971）523-537頁。

44）長山雅一「前期難波京と京の建設をめぐって」(難波宮址を守る会編『難波宮と日本古代国家』，楟書房，1977）119 -128頁。

45）拙稿「難波京域の歴史地理学的考察」((財)大阪市文化財協会『難波宮址の研究第 7, 論考編』, 1981) 105一-136頁。

46）岸俊男「都城と律令国家」(『岩波講座日本歴史 2 』，岩波書店，1975）266一268頁。

47）吉田晶『古代の難波』，教育社，1982，181-186頁。

48）長山雅一「第137次発掘調査概報」（(財)大阪市文化財協会『難波宮跡研究調査年報1975一-1979.6』，1981）118一-123 頁。

49）植木久「難波宮および難波京内出土の墨書土器」，蔁火 4 号，1986，8頁。 
道」を設けて，古来の官道である磯歯津道・大 津道・丹比道との連絡をはかるにとどまったと し，本格的な京の企画を天武朝に和ける飛鳥浄 御原令編纂の準備段階に求めている〔注47〕 173178頁了。

しかし，これらの見解も前期難波宮が長柄豊 碕宮に遡及することを前提としたものである。 前期難波宮＝長柄豊碕宮説は，半ば定説のごと く考觉られる傾向にあるが，中尾芳治の指摘に もあるように，もろもろの状況証拠の積上げに よる可能性, 蓋然性の高さに基づく仮説の域を 出ないのが現状である.

前期難波宮が孝德朝の長柄豊碕宮飞遡及する か否かは，我が国に晾影る宮室の発展過程や条 坊制都市の成立を考学る上で重要な意味を持ち， 大化改新の歴史的評価とも大きく係わる問題で ある。この問題については, 難波宮調査の現状 とこれまで述べて来た藤原宮以前の他宮都の現 状を整理しつつ再度検討を行ら必要がある。

\section{IV 前期難波宮の造営時期をめぐる諸問題}

これまで藤原京を含めて，それ以前の倭京・ 大津宮 (京) ・難波宮 (京) に和将調査研究の 現状を整理して来た。その結果，藤原京では明 らかに条坊制都市の成立が認められるものの， 倭京や大津宮では, 条坊地割の存在を示す遺構 も未だ検出されて抢らず，狭隘な地理的条件か ら見ても条坊制都市の成立はすず想定し難いと する結論が得られた。また，大津宮では藤原宮 に見られる内裏・朝堂院を南北配する大規模 な宮室乞のものも立地不可能である可能性が強
く，飛鳥の諸宮室についても，検出例は少ない が狭縊な地理的条件からみて同様な傾向が窥わ れる。

ただ，前期難波宮のみが，藤原宮と同じよう 飞大規模な内裏・朝堂院を南北に配する宮室構 造を採用し, 宮室の規模や内裏・朝堂院内の殿 舍配置にいくつかの近似点が認められ，両者と も南に開放された地に立地する。これらは飛鳥 の諸宮室や大津宮とは大きく異なる特徴であり, 前期難波宮の造営段階に藤原京のような条坊地 割を伴ら京の建設がすでに企図されていたこと を十分に筧わせる事実と言える。

果して, 前期難波宮の造営段階にどの程度宮 域あるいは京の建設が進行していたのであるら か。それを知る手立として，藤原宮と同じ方約 $1 \mathrm{~km}$ と推定される宮域内での宮造営に伴う地 業の規模や殿舎の分布を整理検討してみる必要 がある。

第 5 ・ 6 図は，今日までの難波宮の調查のう ち上町層上面レベルが明らかな約 200 カ所の調 查と, 大阪城内で害施されたボーリング調査か ら得た上町層 (地山) 上面の標高值をもとに作 成した微地形図上に発掘調査で確認された前・ 後両期の難波宮に伴う整地層, 掘立柱建物の検 出地点を示したものである。両図を見ると，前 -後両期の掘立柱建物等の遺構と整地層の分布 状況が，それぞれ密接な関係を持っていること を窥らことができる。

すなわち, 前期難波宮の場合, 関連建物や整 地層の広がりがきわめて狭く, 整地層が宮中心 部和よび南部の限られた地域に存在するのと同

50）中尾芳治「難波宮跡10年来（1970～1980年）の調査成果と研究動向」(『難波宫址の研究第 $7 』$ 論考編，(財)大阪市文 化財協会) 311頁。

51）拙稿「上町台地北部の微地形々難波宮下層遺跡掘立柱建物」(『難波宮址の研究第 8 』（財)大阪市文化財協会, 1984) 194-208頁。

52）各種データの整理には下記の文献を使用した。

『難波宮址の研究第 1 』, 大阪市立大学難波宮址研究会，1956，『同第 2 』，1958，『難波宮址の研究第 3 第 6 』, 大阪 市立大学難波宮址研究会・難波宮址顕彰会，1959，1961，1964，1970，『難波宮址の研究第 7 』報告編，(財) 大阪市文 化財協会，1981，『難波宮跡研究調査年報1971～1974』，難波宮址顕彰会，1972，1973，1974，1976，『難波宮跡研究調 查年報1975 1976.6』, (財) 大阪市文化財協会, 1981, 『森之宮西之町遺跡第 1 次調查概報』, 森之宮西之町遺跡発掘調 查団，1972，なお，1980年度以降のデータについては，各年度の(財)大阪市文化財協会の発掘調査成果をもとにした。 


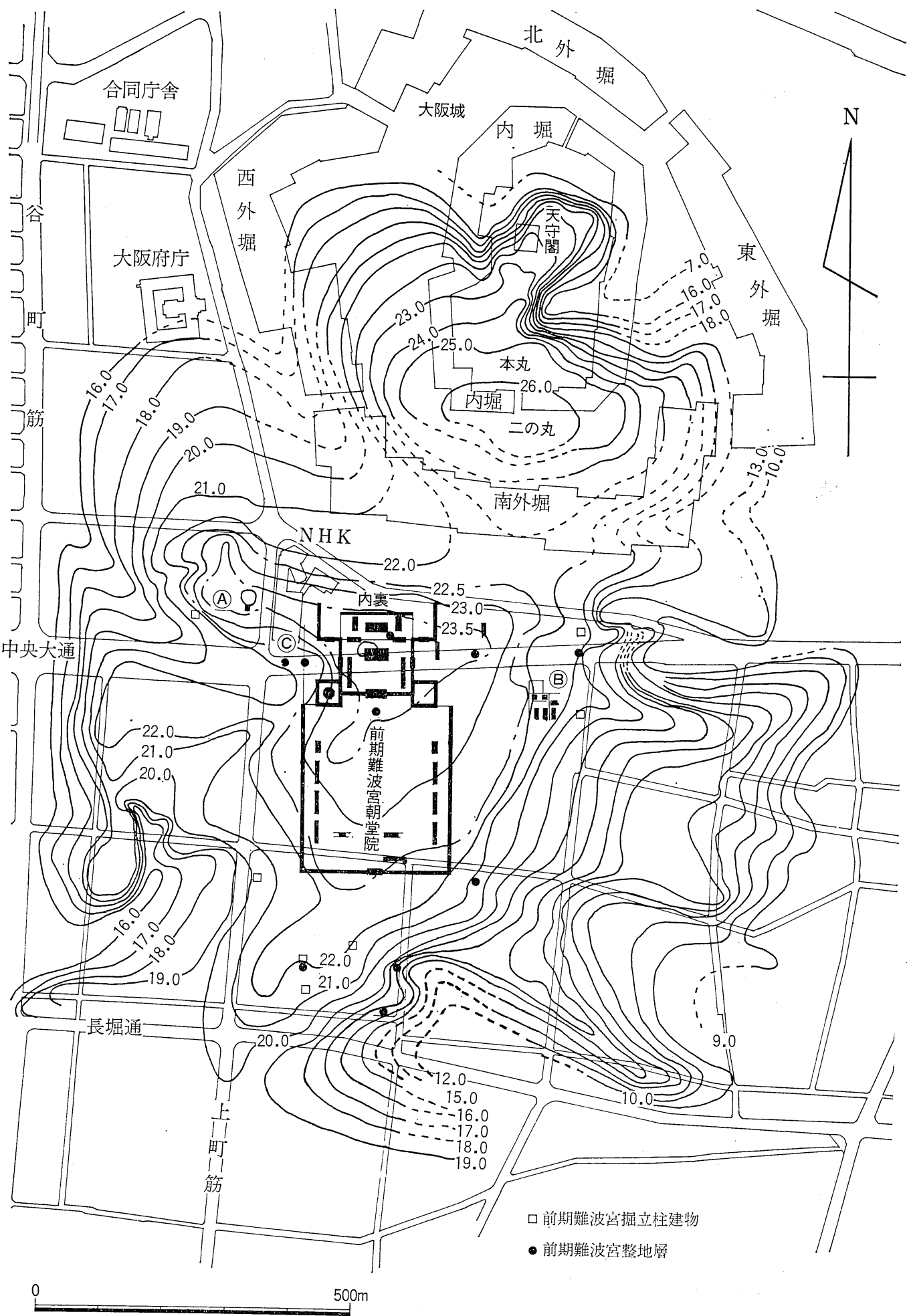

第 5 図 前期難波宮掘立柱建物・整地層分布図

（Nは難波宮北を示す。数值はＯP ( T P + 1.3m) を示す。1985年現在） 


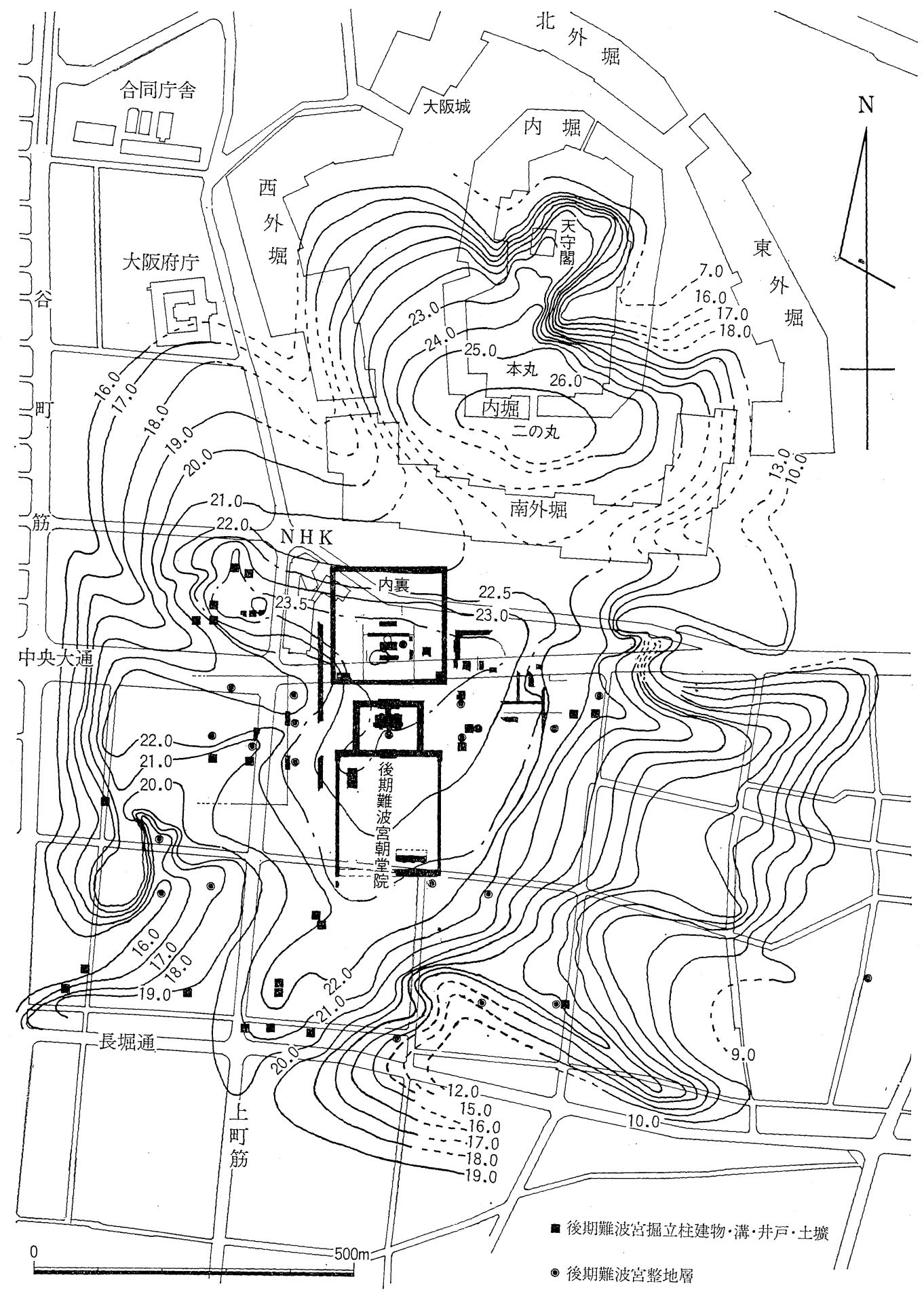

第 6 図 後期難波宮掘立柱建物等検出遺構及び整地層分布図 （Nは難波宮北を示す。数值はOP $(T P+1.3 \mathrm{~m})$ 示す。1985年現在） 
様に，関連遺構も $\mathrm{OP}+20.0 \mathrm{~m}$ 以上の 台地平 坦部といら限られた地域に分布し，乙か子周辺 部では，建物が群在する(B)地区を除けば，宮北 西部の(A)地区拈よび朝堂院南部に点在するに過 ぎない。

それに対して，後期難波宮は周辺の開析谷に まで整地が抢よび，掘立柱建物等の遺構も整地 層の広がりとオーバーラップし広範囲におよぶ。 内裏の北部を含めて北側が大阪城の関係で潘と んど未調査に近いという現状を考慮すれば，方 約 $1 \mathrm{~km}$ の推定宮域の注ぼ全域にわたって掘立 柱建物を中心とする諸遺構が分布すると見るこ とも妥当かと思われる。

前・後両期の地業・建物の分布状況に認めら れるこのような相違は，先にも述べたように前 期難波宮が当初から京の建設を企図していた可 能性が強いことを考慮すれば，やはり『日本書 紀』朱鳥元年 (686) 正月の「難波大蔵省失火, 宮室悉焚。」に見られる 難波宮の 焼失により, 前期難波宮・京の造営が事実上頓挫したことを 物語ると考光ざるを得ない。

さて, 藤原京の造営開始の時期は, 岸俊男に より従来『日本書紀』天武 13 年 (684) 3 月の 「天皇巡三行於京師_，而定=宮室之地。」」である とされて来た。しかし，近年の藤原宮内での先 行条坊道路の検出や本薬師寺の調査成果をもと に, 本薬師寺の造営の始まる天武 9 年 (680) あ るいはそれより遡るのではないかとする見解が， 井上和人〔注11）40頁〕や山中敏史から提示され ている。そうなると，京の造成工事が天武天皇 没後，本格的な都城建設の開始されたと考光ら れる持統 3 年 (689) 頃まで継続的に実施された とは考兄られないが，持統 8 年 (694) 12月の完 成まで10年程度の造営期間を想定することが可
能であろう。

ところで，『日本書紀』天武 8 年 (679) 11 月 の「仍難波築=羅城-。」の羅城は，岸俊男〔注46) 266-268〕や吉田晶の指摘〔注47) 174一-175頁〕する ように難波京の造営を意味すると解せるが，先 の想定に従えば，藤原京と注ぼ同じ頃に前期難 波京の造営が開始されたと考えられる。

前期難波宮が調查関係者の主張するように， 孝徳朝の長柄豊碕宮が天武朝まで存続していた のを利用し，それを一部改造・補修して再用し たものとすれば，第 5 図に見られる前期難波宮 の諸殿舎の造営やそれに伴う基礎地業は, 造営 開始の時期を中尾芳治の指摘に従い最大限繰上 ゲて『日本書紀』大化元年 (645) 冬12月条の 「天皇遷=都難波長柄豊碕。」に求めると，白雉 3 年 (652) 秋 9 月条の「造 $v$ 宮己訖。其宮殿之状, 不 $\nu$ 可=㪷論。」」至る約 7 年と天武 8 年 11 月条 の「仍難波築=羅城。」から朱鳥元年の燒失に 至る約 6 年を合わせた約13年間に施行されたこ とになる。

約13年といら造営期間は，先に述べた藤原京 の10年程度という造営期間と比較しても遜色は なく，朱鳥元年の焼失時点で宮域内の殿舎はも とより基礎地業や条坊地割もほぼ完成していな ケればならない。しかるに，発掘調査から知ら れる前期難波宮の実状は，先に述べたよらに台 地上の平坦地を選んで基礎地業を施行し，殿舎 を配置しているといら程度であり，藤原宮に見 られるような大規模な造成工事には程遠く，後 期難波宮に扝ける基礎地業や殿舎分布と比較し ても先の規模ははるかに小さい。とすれば，や はり大化元年に前期難波宮の造営開始を求める ことは無理と言わざるを得ない。

また，門脇禎二の指摘にあるように，孝德紀

\footnotetext{
53）宮域内のこのような状況は，後期難波宮に括ける京の存在をさらに確実なるのとすると言える。

54）奈良国立文化財研究所「本薬師寺西南隅の調查」，飛鳥・藤原宮発掘調査概報 6，1976，49-55頁。 同「本薬師寺第 2 次調査 (寺域東半部)」, 飛鳥・藤原宮発掘調查概報14，1984，27一29頁。

55）山中敏史「律令国家の成立」(『日本考古学 6 変化と画期』，岩波書店，1986）275頁。

56）門脇禎二「いわゆる難波遷都について」（赤松俊秀教授退官記念事業会編『赤松俊秀退官記念国史論集』, 1972）91一 105頁。
} 
大化元年12月条の「遷都」記事を「遷宮」記事 と理解し，長柄豊碕宮の造営着手を『日本書 紀』白雉元年 (650) 冬10月条の「爲入っ宮地一, 所 壞=丘墓, 及被 $レ$ 遷人者, 賜 物各有 $レ$ 差。即 遣=将作大匠荒田井直比羅夫, , 立=宮堺標_。」 に求めたとしても，白雉 3 年 (652) 秋 9 月には 宮殿はすでに完成して抢り，第 5 図に見られる 基礎地業や殿舎は 2 年足らずの短期間で施行さ れたと考兊ざる得ない。とすれば，宮周辺部 は天武朝の 6 年間の造営期間中にほとんど工事 が実施されなかったという理解し難い結論を生 ぜしめ，白雉元年に長柄豊碕宮（前期難波宮）の 造営開始の時期を求めることにも問題が多いと 言える。

ところで，前期難波宮が朱鳥元年 (686) 正月 に焼失した天武朝の難波宮に比定できることは, 発掘調查で検出される柱穴の大部分に火苂痕跡 が認められることや，後期難波宮との前後関係 からみても異論のないところである。しかし， その造営年代がどこまで遡源し得るかという問 題については，従来考古学・文献史学を含めて 幾多の論争がなされて来た。

これまでの発掘調査の成果を根拠として, 前 期の遺構全体が孝徳朝の長柄豊碕宮まで遡り得 るとする調査関係者の見解〔注50)99-104頁〕は, 推古朝の小墾田宮の段階ですでに朝堂が存在し て抢り，孝徳朝の段階で前期難波宮にみられる ような朝堂院的なものがあっても問題はないと する岸俊男・・狩野久〔注21)226頁〕の見解をはじ め，前期難波宮の東・西長殿を具備した内裏前 殿一画の構造は，大化元年の難波遷都に伴い難 波に設置されていた朝廷の出先機関である小郡
を改築して営まれた小郡宮の段階にすでに認め られ，この内裏前殿一画の前面に朝堂を持つ朝 堂院を付加する形で新造されたのが難波長柄豊 碕宮であったとする直木孝次郎の見解，さらら は，前期難波宮の構造は，官制よりもむしろ冠 位の授与を基調とする君臣関係の拡大と，全 「有位者」が参加する 国家的行事ならびに「朝 参」のありかた，および口頭伝達によって行わ れる執務形態の 3 つの面から理解すべきである とし，朝堂院の規模が巨大である理由を畿内政 権の被支配者達に内裏・朝堂院の壮大さ，その 威容を実見させ彼等を压迫することにあったと した早川庄八などの指摘を得て，和和む称妥当 とされて来ているようである。

しかし，これら文献史学側からの前期難波宮 =長柄豊碕宮説を支持する見解にもいくつか問 題がある。前期難波宫に見られる朝堂院の成立 を推古朝の小墾田宮に求めようとする岸・狩野 の見解は, 形態上の類似のみを強調し, 宮室の 規模の問題を無視しているように思える。推定 豊浦宮（東西100m，南北150２00m）や斑鳩宮・ 川原宮 (1 辺 $200 \mathrm{~m}$ 以下) の推定規模から窥兄る 7 世紀中頃までの宮殿の規模は，山中敏史の指 摘〔注55〕263-264頁〕にあるように後の内裏の範 囲に相当するものであり，前期難波宮のよう に内裏・朝堂院からなる南北 $450 \mathrm{~m}$ 以上, 東西 $240 \mathrm{~m}$ 以上の大規模なるのではない。

また， 7 世紀中頃以降の宮室の大きさと構造 を概観すると，大津宮は前期難波宮を縮小・変 形したものと推定されて扣り[注37)130頁〕, 天武 天皇の飛鳥浄御原宮と推定されている伝承飛鳥 板蓋宮上層遺構 ( 7 世紀後半 末), 飛鳥河辺行

$57 ）$ 岸俊男「朝堂の初歩的考察」(橿原考古学研究所編『橿原考古学研究所論集』，吉川弘文館，1975）509一541頁。

58）直木孝次郎「難波小郡宮と長柄豊碕宮」（難波宮址を守る会編『難波宮と日本古代国家』，塙書房，1977）41一78頁。

59）早川庄八「前期難波宮と古代官僚制」，思想703号，1983，52-68頁。

60）ただし，押部圭周のように前期難波宮の遺構を『日本書紀』大化 3 年「是歳，壊二小郡-而営レ宮。天皇處二小郡宮-， 而定_禮法ー。」にみられる小郡宮に比定する説すある。 押部圭周「難波小郡宫について」，続日本紀研究173号，1979，29-36頁。

61）㗲原考古学研究所編『飛鳥京跡一』, 1974, 81-268頁。 同『飛鳥京跡二』, 1980，1-164頁。 西口寿生「飛鳥諸宮一飛鳥浄御原宮跡推定地に持ける最近の調査を中心として一」，仏教芸術154号，1984，13一17頁。 
宮の候補地とされている飛鳥稲淵宮殿遺跡（7 世紀中頃〜末) や飛鳥寺の北西に位置し，飛鳥浄 御原宮の推定地ともされている石神遺跡 (7世 紀中頃〜後半) は，いずれも全貌は明らかにされ ていないものの，山中敏史の指摘〔注55)271-272 頁了にもあるよらに地形・寺院等の制約から前 期難波宮のような大きな宮城プランの存在は想 定し難い。

とすれば，先の早川庄八の指摘にあるよらな 巨大な朝堂院は，その後の近江や飛鳥の宮都に 継承されず，突如として持統朝の藤原宮に復活 するという理解し難い現象を想定しなければな らない。

また，前期難波宮が孝德朝の長柄豊碕宮に遡 り得るとする考古学側から提示された根拠自体 にもいくつかの問題点が認められる。

第 1 点は，長柄豊碕宮の完成 した白雉 3 年 （652）12月から焼失した朱鳥元年（686）正月ま で33年を経過する老朽化した宮殿建物を継承し たとすれば，内裏前殿・後殿，朝堂建物や門之 いった重要な建物が造替されて当然であるのに， 現実には内裏前殿左右前方の東・西長殿を除け ば，主要殿舎に造替の痕跡が認められないこと である。このような造替の実態は，天武朝造営 時に和ける設計変更に伴ら造替とも考允られる。

第 2 点は, 主として台地周辺の古墳, 難波宮 下層遺跡および地山が供給源であったと考兄ら れる整地層に含まれる遺物の大半は，当然のこ
とながら 5 世紀中葉〜 7 世紀前半に属するもの であり, 出土遺物の年代が必ずしも整地層の時 期を推定する指標とはなり得ないといら事実で ある。そ故に，従来前期難波宫の整地層と報 告されていたものの中にも，第 5 図の(C地点の ようにその後の調査で後期難波宮の整地層と判 断すべきものも生じている。

第 3 点は造営尺をめぐる問題である。前期難 波宮の造営尺については，中尾芳治により 1 尺 $29.2 \mathrm{~cm}$ という寸法が基準尺として復原されて いる。事実, 中尾が指摘するようにこの復原尺 で柱間寸法が完数になる例が多いが，内裏前殿 - 後殿間の東西柵に付属する東西建物, 内裏南 門西回廊, 朝堂院西第 1 堂・第 2 堂, 朝堂院南 回廊では 1 尺 29.4 29.5 cm の造営尺が，ま た内裏東門では 1 尺 $29.8 \mathrm{~cm}$ の尺度が使用さ れたと考兄られる例も認めら机る。

さらに， 7 世紀中葉〜末にかけての飛鳥・藤 原地域に和ける諸宮殿の造営尺をみると，7世 紀中葉に造営された飛鳥稲淵川西宮殿遺跡では 1 尺 $29.3 \mathrm{~cm}$ の造営尺〔注62) 48頁〕が，7 世紀 後半の造営とされる伝承飛鳥板蓋宮上層遺構で は1尺 $29.2 \mathrm{~cm}^{67)}$ が， 7 世紀末を遡らないエビ ノコ郭でも 1 尺 $29.5 \mathrm{~cm}$ が，さらに，7 世紀 末の藤原宮で 1 尺 29.3 29.6 cm の造営尺が 用いられたことが明らかにされている。また， 宮殿ではないが，7 世紀中葉に造営された山田 寺では，金堂・回廊で 1 尺 $30 \mathrm{~cm}$, 講堂・塔で

62）奈良国立文化財研究所「稲淵川西遺跡の調査」，飛鳥・藤原宮跡発掘調査概報 7，1977，43-49頁。

63）造営期間中の設計変更に伴う造替の例として, 難波宮中軸線の西方 $158 \mathrm{~m} て ゙$ 最近検出された五間門の取り付く㘿で囲 まれた後期難波宮の遺構がある。 植木久「難波宮朝堂院西方に五間門」，莘火創刊号，1986，4-5 頁。

64）国立大阪病院南部で実施した難波宮跡第97次・122次調査では，同一開析谷内を埋めた後期難波宮造営に伴ら整地層 を約 $350 \mathrm{~m}^{2}$ 調查したが，出土遺物のほとんどが 7 世紀中葉以前に属するものであり, 後期難波宮期の遺物として平瓦 片数点が出土したに過ぎない。

(財)大阪市文化財協会編『難波宮址の研究第 8 』, 1984，52-56頁。

65） N H K 大阪放送局南側の中央大通りに位置する大阪府道高速大阪東大阪線 の工事に伴う調査（難波宫跡第 100 次 · 112次調查）のMP-1，MP-2 区で検出された整地層である。南接する第84-30次調查地と同じ開析谷の谷頭部に位置

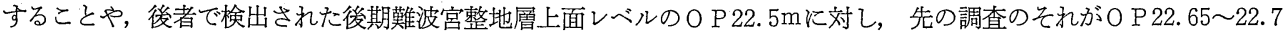
$\mathrm{m}$ とほ浪同じ值を示すことによる。

66）中尾芳治「前期難波宮をめぐる諸問題」，考古学雑誌 58 巻 1 号，1972，1-29頁。

67）秋山日出雄「飛鳥宮室の復原的考察」(橿原考古学研究所編『飛鳥京跡二』，1980）147一164頁。

68) 「飛鳥京跡昭和 52 年度発掘調查概報」（橿原考古学研究所編『奈良県遺跡調査概報 1977 年度』, 奈良県教育委員会, 1978） 141-151頁。 
1 尺 $29.75 \mathrm{~cm}$ といら長い尺度が使用されてい る。

このよらな事実は，山中敏史も指摘する〔注 55）269-270頁〕ように，同じ宮殿遺構の中でも単 一の尺度が使用されたとは限らず，造営に使用 された尺度が必ずしも造営年代を推定する根拠 とはなり得ないことを示唆していると言兄よう。

第 4 点は, 前期難波宮の遺構の中で, 内裏中 心部所在する内裏南門，内裏前殿，内裏後殿， 八角殿や八角殿院回廊などの建物の本柱外方に 付属する小柱穴の性格にかかわる問題である。

問題の小柱穴は，当初飛鳥寺東金堂の下成基 壇上の小礎石を軒支柱とする見解に従って，前 期難波宮の建物が創建後一定の時間が経過した 後に，軒を補強するために支柱を付加したもの と解釈され，とれをもって前期難波宮が孝德朝 まで遡り得る証左の 1 つさされて来た。ところ が，最近では内裏中心建物の外観を荘綮するた めか，建物を大きく強化するために当初から設 置された裳階的なものとする解釈に改められ， 先の論拠の 1 つを失うものの, 前期遗構が孝徳 朝まで遡るとする考学を修正する必要はないと している。

しかし，この小柱穴をめぐっては，軒支柱や 裳階様のものとみる説の他に，縁束説や足場穴 説〔注55）268一-269頁〕もあり，今後その性格につ いてさらに検討を加壳る必要があると考光られ， 現段階で裳階様のものと結論するにはいささか 危惧がある。

他にも問題があるが，以上述べて来た種々の 問題点を考慮するならば，考古学側から提示さ
れた前期難波宮遺構を長柄豊碕宮に遡源させ得 るとする根拠も説得力に乏しいと言わざるを得 ない。

これまで述べて来たように，前期難波宮遺構 を長柄豊碕宮に遡及させ得るとする文献史学や 考古学側の根拠には理解し難い点も多く, 発掘 調査によって明らかにされた前期難波宮の基礎 地業と建物分布の実状や造営期間の問題を考慮 すれば，前期難波宮の造営時期は孝德期に遡及 させるよりも天武 8 年から朱鳥元年の 6 年間と 考觉るべきであろう。

\section{$\mathbf{V}$ 摂津・河内の直線古道と前期難波京}

摂津・河内の直線古道と言えば，かつて岸俊 男が『日本畫紀』壬申の乱の記事中に見觉る大 津道と丹比道に比定した長尾街道と竹ノ内街道, 秋山日出雄がその存在に注目し，服部昌之が 「雄略紀」14年条に見られる磯歯津道にあてら れないかと指摘した八尾街道がある。これら 3 古道は, 足利健亮・秋山日出雄・服部昌之らが 指摘するように, 竹ノ内街道と長尾街道が 1 町 $106 \mathrm{~m}$ の 17 町 (足利説では 18 町), 長尾街道と八 尾街道が同じく34町ときわめて計画的に測設さ れている。

古道測設に際する計画性は, 奈良盈地の上ツ 道・中ツ道・下ツ道の南北 3 古道の相互の間隔 （約20町）にも見られ，岸俊男による想定藤原京 域もこれら古道と密接な関連を示す。藤原京条 坊の規模は約 $265 \mathrm{~m}$ 四方 (令制の 2 町半) である から，106m 1 町の単位は古代の都市計画 とも 言える条坊制地割の基礎単位であったとも言壳

69）奈良国立文化財研究所「山田寺第 4 次（東回廊跡）の調查」，飛鳥・藤原宮跡発掘調查概報13，1983，32一44頁。

70） 奈良国立文化財研究所編『飛鳥寺発掘調查報告』，1958，43頁。

71）『難波宮址の研究第 6 』, 大阪市立大学難波宮址研究会・難波宮址䫒彰会，1970，97一98頁。

72）『難波宮址の研究第 7』報告編，(財)大阪市文化財協会，1981，157一160頁。

73）岡田英男『第 4 回大阪の歴史を掘る講演会資料』，1985.

74）岸俊男「難波一大和古道略考」(小葉田渟教授退官記念事業会編『小葉田淳教授退官記念国史論集』，1970）81一92頁。 同「古墳の歴史」(坪井清足・岸俊男編『古代の日本 5 近畿』，角川書店，1970）93-107頁。

75）秋山日出雄「日本古代の道路と一歩の制」(橿原考古学研究所編『橿原考古学研究所論集（創立35周年記念)』, 吉川 弘文館, 1975）543一582頁。

76）服部昌之·古代の直線国境について」，歴史地理学紀要17，1975，5－29頁。 
る。

ところで, 岸俊男は先の摂津・河内の直線古 道の測設時期を壬申の乱 (672年) 以前に求めて いるが，筆者はかねてより難波に和ける京の成 立時期と深くかかわるのではないかと考光て来 た。

最近, 大阪市南部に位置する 2 遺跡で八尾街 道の測設年代を推定する上で興味ある調査成果 が得られた。1つは南住吉遺跡にあたり，千田 稔の推定する住吉郡家の南で八尾街道の北約 60 $\mathrm{m}$ の地点 (第 8 図のP) での発掘調査 (MN 85-37 次調查)である。この調查では第 7 図に示すよ らに，大さく 3 時期に区分される掘立柱建物や 溝が検出され， 7 世紀前半以降の出現とされる 2 時期の建物群がN11〜14度 E⿱ あいは北で西 に振れる棟方位を示すのに対して，最も新しい 時期の建物群は八尾街道と同じほぼ正方位を示 し，7世紀末に近い年代が与兄られている。

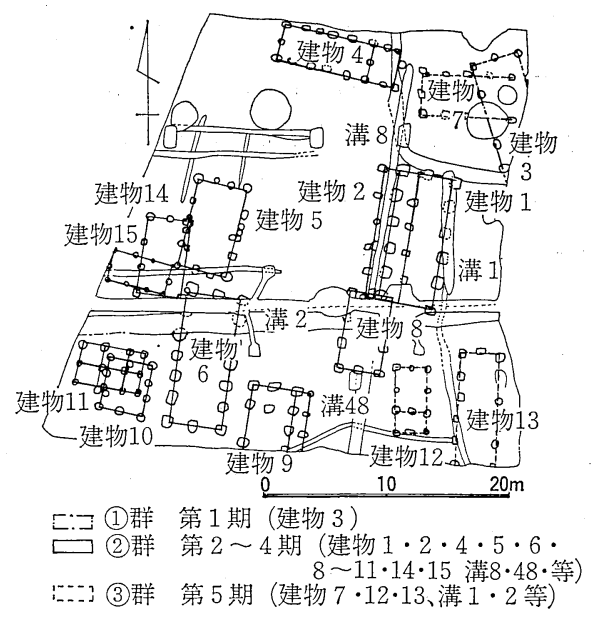

第7図 MN85-37次調査検出遺構 (「蔁火 2 号」による。Nは公共座標の北)
もら1つは，八尾街道沿いに位置する城山遺 跡での発掘調査 (第 8 図のQ) である。この調査 では規格性の乏しい配置を示す畦畔群の中に, $110 \mathrm{~m}$ の間隔で測設された 2 条の大畦畔 (幅70〜 $120 \mathrm{~cm}$, 高さ $40 \mathrm{~cm}$ ) で北と南を画した正方位の 水田が検出され，その経営の時期は，大畦内出 土の墨書土器から 7 世紀後半〜末葉と推定され ている。この正方位水田は, 以前の非規格水田 を部分的に改变したものであり，北を画する大 畦畔は八尾街道から南約 $530 \mathrm{~m}(106 \mathrm{~m} \times 5$ 町) に 位置し，八尾街道を基準に測設された可能性が 大きいと言える。

このような八尾街道沿いの 2 遺跡に和将る発 掘調查の事例は，八尾街道が注注正東西の直線 道路として整備される時期を 7 世紀後半〜末頃 に想定することを妥当とするものである。それ 以前の八尾街道は，和そらく住之江に注ぐ細江 川沿いに上町台地にのぼり，地形の微妙な変化 に左右されつつ部分的に曲折しながら東に向か ら道であったと考兄られ，そのような道が『日 本書紀』雄略天皇14年条に見られる「磯歯津路」 の姿ではなかったかと思われる。奈良盆地の計 画古道である上ツ道・中ッ道・下ツ道の南北 3 道と直交する横大路の出現に見られるように， 正東西道路の出現の背景にはやはり正南北道路 の成立を考觉るべきであろう。

摂津・河内に抢汗る当該期の南北道路と言党 ば，難波宮中軸線の延長線すなわち推定朱雀大 路の延長道路（第8図のS・T・U）もしくは， 岸俊男により指摘され発掘調査によって検証さ れた 7 世紀中葉を遡らない頃の測設とされる難 波大道（第 8 図の $\mathrm{V} \cdot \mathrm{R} \cdot \mathrm{W}$ ) 以外飞は考光られ

77）千田稔『埋れた港』, 学生社, 1974, 140一-145頁。

78）積山洋「南住吉遺跡で発見された 7 世紀の建物群について」，蔁火 2 号，1986，4-5 頁。

79）大阪市平野区の中央環状線沿いに位置する遺跡であるが，この地域で発掘調査が開始された1974年頃は，長原遺跡と 別の遺跡として当該遺跡名が付されたが，今日では長原遺跡の中に含まれている。

80) 藤永正明・阿部幸一「城山遺跡水田跡出土の墨書土器」, 大阪文化誌第18号, 1985，49一-54頁。 藤永正明「水田について」(『城山（その3)』，大阪府教育委員会・(財)大阪文化財センター，1986）92一97頁。

81）八尾街道は現存する丹比郡条里の里界線の北 2 町半という中途半端な位置を東西に貫くため, 当然のことながら問題 の正方位水田も現条里地割とは約半町ずれる。






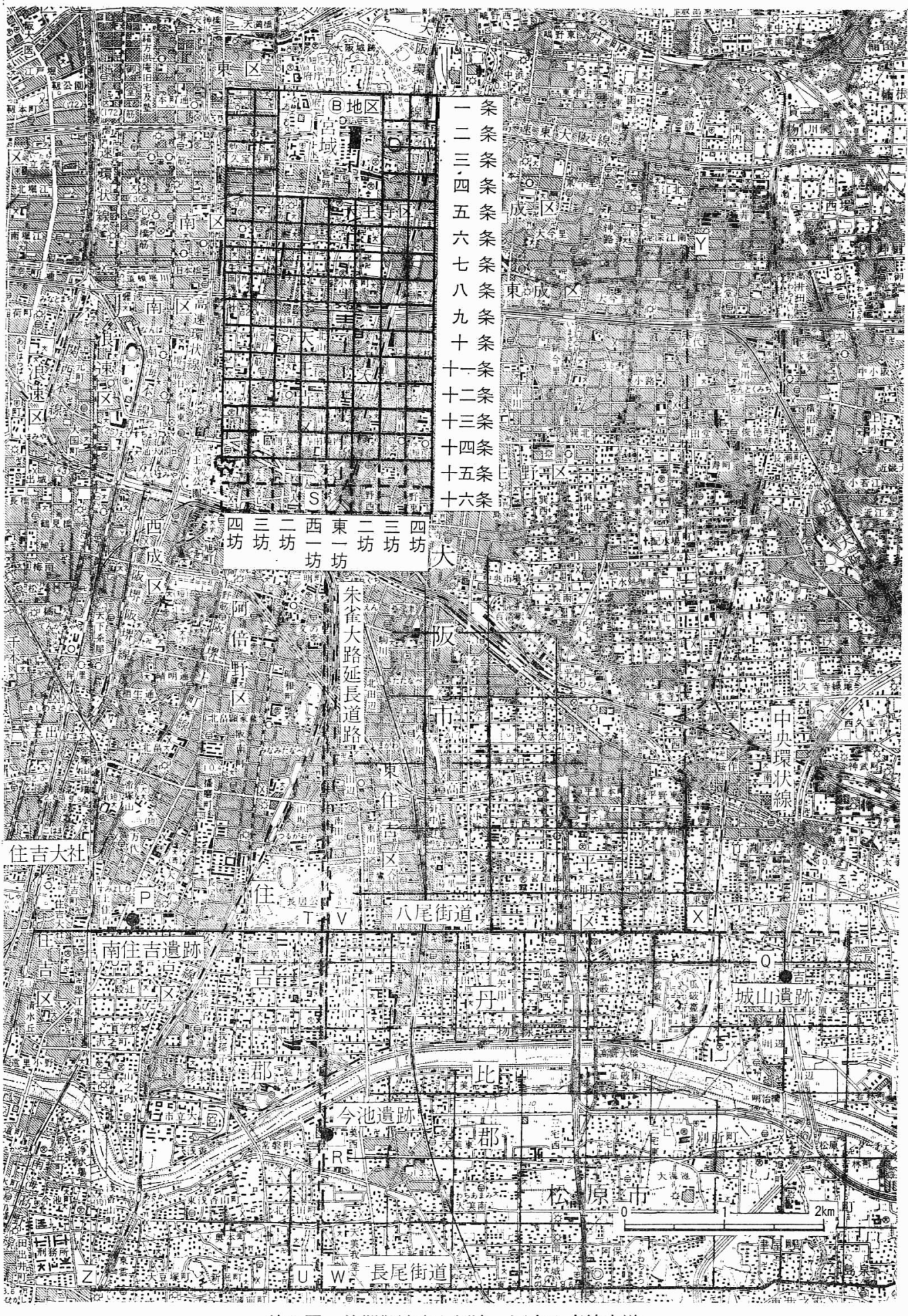

第 8 図 前期難波京と摄津・河内の直線古道

$\searrow$ 頁。

83）大和川 · 今池遺跡調査会『大和川 · 今池遗跡 III $1981 ， 82$-105頁。 
ない。従来これら両道は真北の方位を有し, 一 直線に通ずる古道と考光られて来た。

しかし，実際には両道は真北でなく，前者は 真北に対して34分44秒東偏し, 後者も約44分注 ど東偏して和り，両者間に約10分の振れが認め られ一直線にはつながらない。これらの方向角 をもとに両道のずれを計測すると，難波宮中心 部の南方約 $7.8 \mathrm{~km}$ に位置する八尾街道上では 前者は後者の西約 $34 \mathrm{~m}$ (第 8 図の T) に，同じく 約 $9.9 \mathrm{~km}$ 南方の今池遺跡の南に位置する国家 座標第 V系の $\mathrm{X}=-156 \mathrm{~km} 500 \mathrm{~m}$ ライン上で は西約 $27 \mathrm{~m}$ に位置することになる。

八尾街道上での約 $34 \mathrm{~m}$ というずれは，古代の 測量技術からすれば容認し得る誤差とも解せる。 しかし，大正 10 年測量の 1 万分の 1 地形図や昭 和 49 年測量の 2,500 分の 1 大阪地形図をもとに 両道々周辺条里の関係を検討すると, 八尾街道 は難波大道之直交せず，むしろ第 8 図の正方位 に近い S V 線や服部昌之により指摘された摂 津・河内の直線国境の 1 つであるXY線〔注76) 8一-17頁了と直交する。また，八尾街道と長尾街 道間の現条里地割の条界線が住吉郡・丹比郡々 も難波大道の方位に合致し, やや東に振るのに 対し, 八尾街道から北の現条里地割は, 先のS V線やXY線に平行もしくは直交しほぼ正方位 を示していることがわかる。

このような事実は，朱雀大路延長道路と難波 大道の測設時期が異なる可能性を示唆するもの と解せ，前期難波京の建設に伴い八尾街道を直 線道として整備し，第 8 図のSからやや西に方 位を振り八尾街道上で旧来の難波大道と $\mathrm{V}$ 点で 接続させたと考觉ることるできる。

そうなると，朱雀大路延長道路の北端に位置 する前期難波宮の遺構气のものの造営時期も 7
世紀中葉を遡らないとされる難波大道と結びつ けて考光る必要はなく, 八尾街道が直線道路と して整備される 7 世紀後半〜末頃，つまり天武 朝に求めるのが妥当かと思われる。

最後に前期難波京の条坊について筆者の見解 を述べて和きたい。かつて筆者は後期難波京プ ランを藤原京と同じ 1 坊を令小尺 900 尺とする 東西 8 坊, 南北14条と復原した。東西幅は奈良 時代初頭の汀線を根拠としたものであるが，南 京極の設定は茶臼山古墳を京内に含めないと考 えたからである。ところが，昭和61年に茶臼山 古墳の発掘調査が始めて実施され，古墳でない 可能性が強くなった。

第 9 図は, 明治 19 年内務省地理局発行の 5 千 分の 1 大阪実測図の天王寺村之国分村付近の字 界を昭和 49 年の 2,500 分の 1 大阪地形図に重水 たものである。この図によると，国分村の南に 字十六といら小字が認められ, 四天王寺境内に 荒陵山といら地名が遺存するのがわかる。茶臼 山古墳が古墳でないとすれば，荒陵山という地 名は『日本書紀』推古天皇元年 9 月条の「始 造=四天王寺於難波荒陵-。」に見られる 荒陵 と 結び付き，四天王寺が飛鳥時代に当地にあった 古墳 (荒陵山)を壊して造営されたと考えること ができる。四天王寺境内から長持形石棺や多数 の埴輪が発見されることは先の推定を裏付ける ことと言えよう。

このように茶臼山古墳が古墳でなく，先の 『日本書紀』に見られる 荒陵を四天王寺境内に 所在した古墳と考觉ると，第 8 図に示すように 1 坊を令小尺 900 尺（約 $265 \mathrm{~m}$ ) とした東西 8 坊, 南北16条の京域を想定することができ, 先 の国分村の字十六はまさしく条坊の16条に合致 することになる。

84）藤岡謙二郎の復原では，朱雀大路延長線は難波大道より条里の約 1 坪分東に偏した位置を通る。これは難波宮中軸線 を真北と考えて朱雀大路延長線を復原したことに起因すると思われる。ちなみに，真北として計測すると，八尾街道上 で難波大道の東方約 $93 \mathrm{~m}$ を通る。

85）趙哲済「茶臼山古墳の発掘調査」，“莘火 4 号，1986，2-6 頁。

86）条坊制に叔秝の初現は平城京からであることを考慮すると，字十六は後期難波京の時期に付されたと考えられる。 




第 9 図 難波京南辺部の地割と小字

そこで，このようにして復原した京域の南京 極から八尾街道までの距離（第8図のS V間）を 2,500 分の 1 地形図上で計測すると, 約 4, 237 $\mathrm{m}$ といら数值が得られる。これは令制の 1 町 $=$ $106 \mathrm{~m}$ の注湆 40 町 $(4,240 \mathrm{~m})$ にあたる。服部昌 之によれば，第 8 図のX V間の距離 む約 34 町 $(3,600 \mathrm{~m})$ となることが指摘されて和り，さら に, 復原した難波京の南北長も40町 $(2.5$ 町 $\times 16$ 条)であり，東西幅も20町 (2.5町 $\times 8$ 坊) とな る。

このような事実は，難波に拈ける東西 8 坊， 南北16条という京の造営が，同じょうに令制の 1 町 $=106 \mathrm{~m}$ という基本単位をもとに計画的に 設置された竹ノ内・長尾・八尾の 3 古道の測設 と密接な関係をもたせて実施されたことを示す ものと考兄られ，炎の造営の時期は，八尾街道 が直線道路として整備される 7 世紀後半〜末,
すなわち，天武朝にあてることがでさよう。

となると，服部昌之の指摘にある摄津・河内 の直線国境（第 8 図の $\mathrm{Y}-\mathrm{X}-\mathrm{V}-\mathrm{W}-\mathrm{Z}$ ) の成 立もこの頃に比定することができ，岸俊男の天 武朝に拉ける京の成立時期に各地の国境が定め られたとする見解とも符合する。

しかし，このような条坊プランを有した前期 難波京も天武 8 年頃に藤原京と平行して企画さ れ造営工事も半ば進むが，朱鳥元年の宮中枢部 の暁失により造営の中絶をみ，神亀 3 年 (726) に始まる後期難波宮の造営を迎兄てようやく京 を含めて完成したと考兄られる。

\section{おわりに}

我が国に新沙る条坊制都市の成立は，地形的 にも狭湓な地に立地し, 宮室の規模も小さい 7 世紀代の飛鳥の諸宮や近江大津宮には想定不可

87）岸俊男「都城が展開した道」(『日本の古代 9 , 都城の生態』，中央公論社，1987）18-19頁。 
能であり， 680 年前後という天武朝の中頃に藤 原京と平行して企画造営された前期難波京に求 めることができる。

しかし, 前期難波京の造営は朱鳥元年の宮室 焼失により工事半ばで中絶し, 藤原京の造営も 天武天皇の崩御により中断する。そして，条坊 制都市の完成は持統 8 年の藤原宮遷都を待た称 ばならない。

前期難波宮の宮室の規模や殿舎構造が藤原宮 と共通する一面があるものの，藤原宮の中心建 物が礎石建物で瓦を使用しているなど細部に到 って相違が認められるのも, 両宮室の設計時期 が約10年と大きくずれることに起因するものと 考光られる。

また，前期難波宮遺構全体を長柄豊碕宮に遡 及させ得るとする見解もあるが，宮域内の基礎 地業や殿舎分布の実状をもとにした造営年数の 検討や摂津・河内の直線古道の検討にもとずけ ば，前期難波宮遺構も天武朝に造営されたもの と理解すべきであり，天武 8 年に始をる難波京 の造営は，宮室の造営をも含めた工事であった と考克られる。

そらなると，長柄豊碕宮は一体何処に存在し たのかといら新たな問題が生じて来る。この問 題について積極的に見解を提示できるほどの資 料は今のところない。しかし，第10図に示した 宮東方の B地区で検出された前期難波宮東方官 衙と考兄られている建物群は，難波大道の北へ の延長線上に位置すること，火災痕跡がなく，

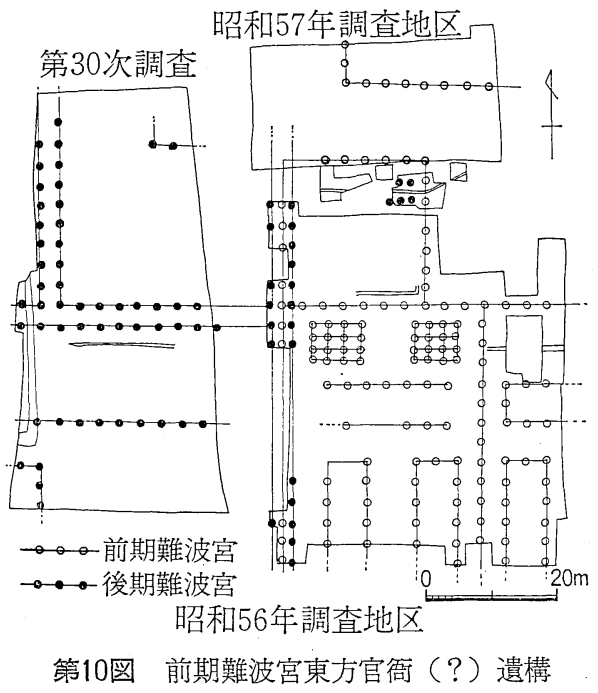

柱抜き取り穴内から 7 世紀後半の土器を出土し ていること，さらには，その規模が南北 $150 \mathrm{~m}$ 以上，東西 $100 \mathrm{~m}$ 以上と推定され，伝承飛鳥板 蓋宮上層遺構やエビノコ郭と比較しても遜色が ないことなどからみて一応注意すべき遺構かと 思われる。

また，難波大道をさらに延長すると，現大阪 城下に達导る。現大阪城下には第 5 図からもわ かるように, OP + $22 \mathrm{~m}$ の等高線で团末れる地 山の広い平坦面があり，宮室の立地も十分に可 能であろう。

本稿を草するにあたり，大阪市立大学の服部昌 之先生をはじめとして（財）大阪市文化財協会の 一部の調查員諸氏から種々の有益な御助言を頂い た。ここに記して深謝の意を表します。

（財）大阪市文化財協会） 